Journal of Teacher Education for Sustainability, vol. 17, no. 1, pp. 48-57, 2015

\title{
Perceptions of the Maltese Public towards Local Marine Protected Areas
}

\author{
Mark Mifsud and Marielle Verret \\ University of Malta, Malta presented
}

\begin{abstract}
The marine environment represents a central component of Malta's local environment, and its ecosystem services play a vital role in supporting the economy as well as human well-being. Plans have been made to protect the unique ecology found within Maltese waters through the institution of five marine protected areas (MPAs). This quantitative study assessed the environmental knowledge and attitudes of the Maltese public towards the local marine environment, MPAs and education for sustainable development (ESD). A questionnaire was administered to members of the public $(n=200)$ at three different locations. The study found that although the Maltese public strongly appreciates the beauty of Malta's marine environment, the level of knowledge surrounding the marine environment is low. Furthermore, the research indicates that while the public agrees that the marine environment should be protected, there is a notable lack of awareness of the five local MPAs. Based on the research findings, a model linking ESD to MPAs and aiming to foster a sense of ownership among the public by encouraging their involvement in the management of local MPAs is proposed.
\end{abstract}

Keywords: marine protected areas, education for sustainable development, quantitative framework, public perceptions, marine protected areas management

The oceans cover about $70 \%$ of our planet (Bollmann et al., 2010) and marine ecosystem services play a vital role in sustaining human well-being (United Nations Environment Programme [UNEP], 2006). However, it is clear that anthropogenic activity has severely altered marine biodiversity (Guidetti et al., 2014), impeding its ability to provide these marine ecosystem services (Worm et al., 2006). In addressing the loss of marine biodiversity, spatial tools such as marine protected areas (MPAs) have been used increasingly throughout the world, and MPAs are now generally regarded as an essential tool for marine conservation (Cullis-Suzuki \& Pauly, 2010).

Acknowledging the interconnectedness that exists between the world's population and oceans (Behnam, 2013), there is evidence that social factors determine an MPA's success (Leisher et al., 2012). The International Union for the Conservation of Nature (IUCN) guidelines for MPAs emphasise the need to gain the public's support through education and to generate a sense of ownership, which, along with community, involvement should serve as the main management tools (Kelleher, 1999). The guidelines also 
suggest that educational efforts are important as they can result in the reduction of MPA enforcement costs (Kelleher, 1999). Regarding the Cairns section of the Great Barrier Marine Park, Alder (1996) found that education programmes were less expensive than enforcement and also resulted in a wider community impact. Furthermore, a study by Thomassin, White, Stead and Gilbert (2010) on Reunion Island stated that, if local communities are accepting of an MPA, then the MPA managers can focus more on conservation activities instead of those related to enforcement.

The Mediterranean Sea is an important site for conservation as it is a hotspot for marine biodiversity (Coll et al., 2010; Mangos \& Claudot, 2013) and is characterised by high rates of endemism as well as habitat diversity (Abdulla, Gomei, Hyrenbach, Notarbartolo-di-Sciara, \& Agardy, 2009; Coll et al., 2010; Portman, Notarbartolo-di-Sciara, Agardy, Katsanevakis, Possingham, \& Di-Carlo, 2013). In confronting the local situation, the Maltese islands have a landmass of $316 \mathrm{~km}^{2}$ (Government of Malta, 2002) in total and a population of about 421,364 (National Statistics Office, 2013). Mangos, Bassino and Sauzade (2010) found that Malta benefits from the Mediterranean's marine ecosystems at a value of 83 million Euros per year. Currently, in Malta, there are five designated MPAs: Grigal ta' Malta, Filfla, Rdum Majjiesa, Mgarr ix-Xini and Dwejra, collectively extending over an estimated $180 \mathrm{~km}^{2}$ or $5 \%$ of Malta's territorial waters (Figure 1).

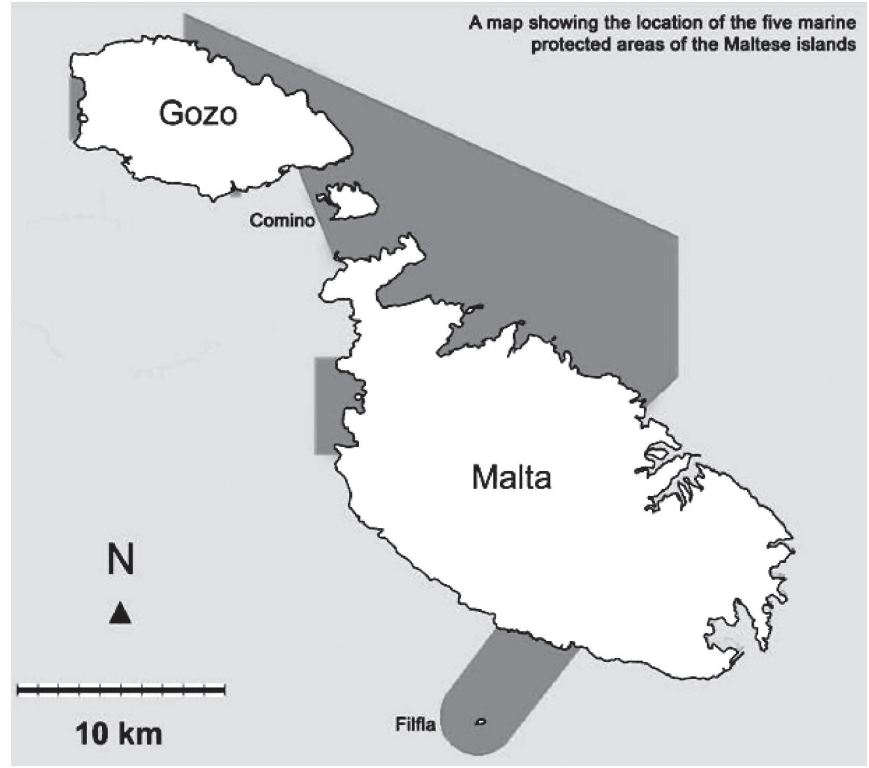

Figure 1. Map depicting the location of Malta's five MPAs

Although management plans have already been drafted or are currently being drafted for all five Maltese MPAs, none have been implemented yet. The designated MPAs have been designed to represent $80 \%$ of Malta's Posidonia oceanica meadows (Malta Environment and Planning Authority [MEPA], 2010). This seagrass species is endemic to the Mediterranean and is particularly important in supporting marine biodiversity since it acts as an ecosystem engineer (Michel, Schnitzler, Dupont, Gobert, Nyssen, Dauby, \& Lepoint, 2011; Personnic, Boudouresque, Astruch, Ballesteros, Blouet, BellanSantini, \& Ruitton, 2014). 


\section{Methods}

The mixed-methods approach was selected as the research methodology, combining the collection of both quantitative and qualitative data. A questionnaire targeting the Maltese public was developed to collect quantitative data, while semi-structured interviews were carried out with key stakeholders for the qualitative data collection. For the purposes of this paper, only the quantitative portion of the research will be considered.

With the Maltese public as the target population, a sample size of 200 was determined based on Malta's population of 421,364 (National Statistics Office, 2013). This sample size $(\mathrm{n}=200)$ allowed for a confidence interval of 6.93 assuming a confidence level of $95 \%$ (Surveysystems.com, 2014). Out of the 200 respondents, $67 \%$ (134) were female, while $33 \%$ (66) were male. With regard to age, $46 \%$ of the respondents within the sample were between the ages of 20-40 (Figure 2).

Three cities were selected for the administration of the questionnaire: Valletta (Malta), Sliema (Malta) and Victoria (Gozo) (Figure 3). Valletta and Victoria represent the capital cities of Malta and Gozo respectively, while Sliema represents an important leisure location compared to the business nature of Valletta. Convenience sampling was employed as the sampling strategy, and respondents were approached in a variety of locations within the three selected cities.

The final questionnaire was administered to the Maltese public during June and July 2014 following an initial pilot study in June 2014. The pilot questionnaire was administered to 20 members of the public in Valletta to represent $10 \%$ of the sample size $(\mathrm{n}=$ 200). Based on the outcome of the pilot study, changes were made to simplify and shorten the final questionnaire. The first part of the questionnaire gathered socio-demographic information while the second part contained statements surrounding the following themes: Knowledge of Malta's marine environment and MPAs; Attitudes towards Malta's marine environment and MPAs, the Delivery of marine education for sustainable development (ESD) in Malta. The questionnaire employed a five point Likert scale, and some state-

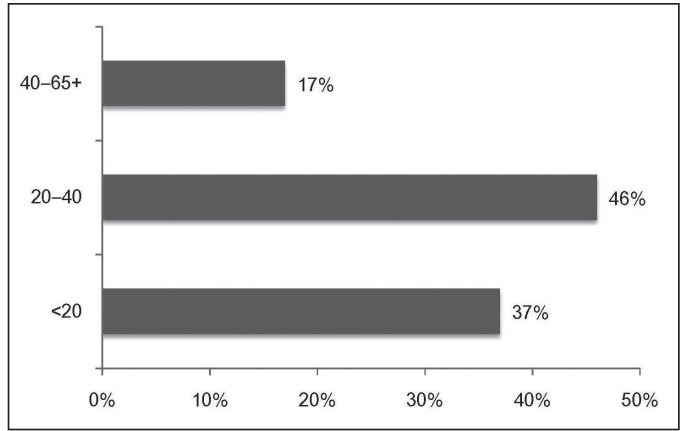

Figure 2. Percentage of sample belonging to different age groups

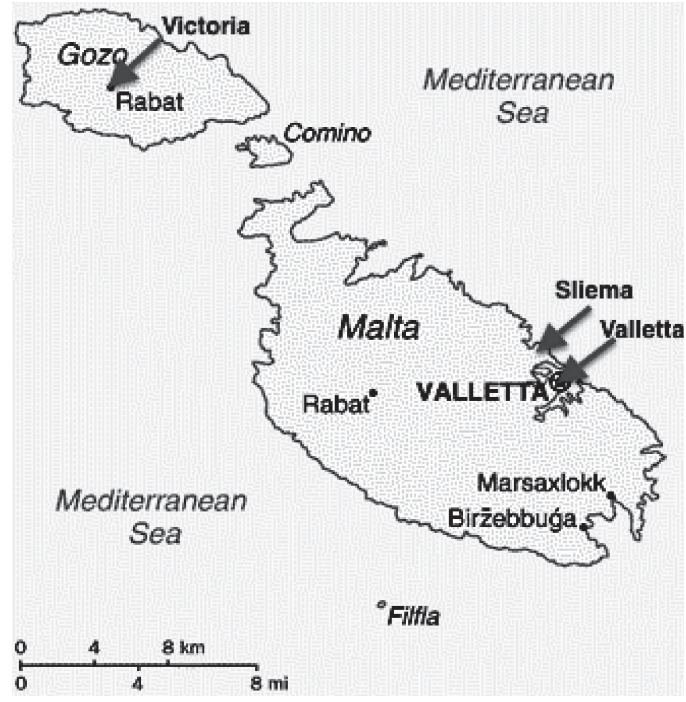

Figure 3. Map of the three cities where the questionnaire was administered 
ments in the questionnaire were adapted from two previous studies addressing a similar research topic (Leisher et al., 2012; Trenouth, Harte, Paterson de Heer, Dewan, Grage, Primo, \& Campbell, 2012).

\section{Results}

\section{Knowledge of Malta's Marine Environment and MPAs}

Respondents were first asked to name an MPA in Malta, and 87.5\% of the sample was unable to do so. Out of the 25 correct answers $(n=200), 17(68 \%)$ named Filfla, 6 (24\%) named Dwejra, 1 (4\%) named Mgarr ix-Xini, 1 (4\%) named Rdum Majjiesa and 0 named Grigal ta' Malta. In addition, low levels of knowledge surrounding the marine environment among the Maltese public were found. As seen in Table 1, 56.5\% of the respondents either disagreed or strongly disagreed that they know a lot about Malta's marine environment. Furthermore, with regard to MPAs, $49.5 \%$ of the sample either disagreed or strongly disagreed that they were familiar with the concept. In addition, $26.5 \%$ of the sample were neutral towards whether the goal of MPAs in Malta are to eliminate human activity from the area, pointing to further uncertainty regarding what an MPA is. However, $87 \%$ of the respondents did agree or strongly agree that MPAs play an important role in conserving Malta's marine biodiversity and resources for future generations, suggesting that the Maltese public is aware of the utility of MPAs.

Table 1

Questionnaire Results in Percentage (\%) for Knowledge Statements ( $n=200)$

\begin{tabular}{lccccc} 
& $\begin{array}{c}\text { Strongly } \\
\text { agree }\end{array}$ & Agree & Neutral & Disagree & $\begin{array}{c}\text { Strongly } \\
\text { disagree }\end{array}$ \\
\hline $\begin{array}{l}\text { I know a lot about Malta's marine } \\
\text { environment. }\end{array}$ & 1 & 16.5 & 26 & 42.5 & 14 \\
\hline I know what marine biodiversity is. & 9.5 & 36 & 15.5 & 27 & 12 \\
\hline $\begin{array}{l}\text { Seagrass in Malta is not important for } \\
\text { marine ecosystems. }\end{array}$ & 3 & 8 & 19 & 38 & 32 \\
\hline I am familiar with the concept of MPAs. & 4.5 & 27.5 & 18.5 & 33 & 16.5 \\
\hline $\begin{array}{l}\text { The goal of MPAs in Malta is to eliminate } \\
\text { human activity from the area. }\end{array}$ & 4.5 & 24 & 26.5 & 29.5 & 15.5 \\
\hline $\begin{array}{l}\text { MPAs play an important role in conserving } \\
\text { Malta's marine biodiversity and resources } \\
\text { for future generations. }\end{array}$ & 30 & 57 & 8.5 & 2 & 2.5 \\
\hline
\end{tabular}

\section{Attitudes towards Malta's Marine Environment and MPAs}

The Maltese public appears to have positive attitudes towards Malta's marine environment and MPAs. In fact, as illustrated in Table 2, 93.5\% of the respondents either agreed or strongly agreed that they appreciate the beauty of Malta's marine environment. Specifically regarding MPAs, $85 \%$ of the sample also either agreed or strongly agreed that they are in favour of MPAs in Malta. However, $27.5 \%$ of the sample was neutral towards whether they could do a lot to protect Malta's marine environment, raising questions of empowerment. Furthermore, $32 \%$ of the respondents were also neutral 
towards whether they want to participate more actively in marine conservation, suggesting a lack of interest in becoming involved.

Table 2

Questionnaire Results in Percentage (\%) for Attitude Statements towards Malta's Marine Environment and MPAs $(n=200)$

\begin{tabular}{lccccc}
\hline & $\begin{array}{c}\text { Strongly } \\
\text { agree }\end{array}$ & Agree & Neutral & Disagree & $\begin{array}{c}\text { Strongly } \\
\text { disagree }\end{array}$ \\
\hline $\begin{array}{l}\text { I appreciate the beauty of Malta's marine } \\
\text { environment. }\end{array}$ & 64.5 & 29 & 4.5 & 1.5 & 0.5 \\
\hline I am in favor of MPAs in Malta. & 43.5 & 41.5 & 12 & 0.5 & 2.5 \\
\hline $\begin{array}{l}\text { An MPA would not benefit my family or } \\
\text { community. }\end{array}$ & 6 & 14.5 & 20 & 39 & 20.5 \\
\hline $\begin{array}{l}\text { There is no hope for improving the marine } \\
\text { environment. }\end{array}$ & 2 & 4 & 12 & 46 & 36 \\
\hline $\begin{array}{l}\text { I can do a lot to protect Malta's marine } \\
\text { environment. }\end{array}$ & 17.5 & 42 & 27.5 & 11 & 2 \\
\hline $\begin{array}{l}\text { I want to participate more actively in } \\
\text { protecting the marine environment. }\end{array}$ & 15.5 & 38.5 & 32 & 11 & 3 \\
\hline
\end{tabular}

\section{Attitudes towards the Delivery of Marine ESD in Malta}

Exactly $91 \%$ of the respondents either agreed or strongly agreed that ESD related to MPAs is important. Furthermore, $86.5 \%$ of the sample also either agreed or strongly agreed that marine ESD should be taught in all Maltese schools. However, uncertainty exists surrounding whether the Maltese public wants to have a say in decisions related to the management of MPAs as $43.5 \%$ of the sample selected neutral. However, $67.5 \%$ of the respondents either disagreed or strongly disagreed that MPA managers should be the only ones responsible for conservation, suggesting that the Maltese public believes a wider range of people should be involved.

Table 3

Questionnaire Results in Percentage (\%) for Attitude Statements towards the Delivery of Marine ESD in Malta $(n=200)$

\begin{tabular}{lccccc}
\hline & $\begin{array}{c}\text { Strongly } \\
\text { agree }\end{array}$ & Agree & Neutral & Disagree & $\begin{array}{c}\text { Strongly } \\
\text { disagree }\end{array}$ \\
\hline ESD related to MPAs is important. & 41.5 & 49.5 & 4.5 & 3 & 1.5 \\
\hline $\begin{array}{l}\text { MPA managers should be the only ones } \\
\text { responsible for conservation. }\end{array}$ & 3.5 & 14.5 & 14.5 & 41.5 & 26 \\
\hline $\begin{array}{l}\text { I want to have a say in decisions related to } \\
\text { the management of MPAs. }\end{array}$ & 6 & 35 & 43.5 & 12.5 & 3 \\
\hline $\begin{array}{l}\text { Marine ESD should be taught in all } \\
\text { Maltese schools. }\end{array}$ & 42.5 & 44 & 10.5 & 2 & 1 \\
\hline $\begin{array}{l}\text { ESD provided by non-formal sectors is } \\
\text { valuable. }\end{array}$ & 31.5 & 52.5 & 14.5 & 0.5 & 1 \\
\hline MPAs should be used for outdoor ESD. & 31 & 54 & 12.5 & 2 & 0.5 \\
\hline
\end{tabular}




\section{Socio-demographic Correlations}

This section of the quantitative data analysis section presents the results obtained from the Chi-squared test. This statistical test analysed the associations between four socio-demographic indicators of the questionnaire respondents (gender, occupation, age, education) and their answers to each statement. Some of the significant correlations obtained are presented in Table 4. As displayed, younger generations in Malta appear to be more familiar with the concept of MPAs but seem to value ESD related to MPAs less than the older generations. With regard to education, a higher level of education is associated to a stronger appreciation of the beauty of Malta's marine environment as well as a stronger sense of responsibility towards protecting the marine environment. As for occupation, students were found to be least in favour of having marine ESD taught in all Maltese schools, perhaps due to a perceived increase in workload. Lastly, men were found to value ESD provided by non-formal sectors, such as non-governmental organisations (NGOs), more so than women in Malta.

Table 4

Selection of Significant Correlations Obtained from the Chi-Square Test

\begin{tabular}{|c|c|c|c|}
\hline & Social indicator & $\begin{array}{l}\text { Chi-squared } \\
\text { result }\end{array}$ & Meaning \\
\hline $\begin{array}{l}\text { I am familiar with the } \\
\text { concept of MPAs. }\end{array}$ & Age & $\begin{array}{l}\mathrm{x}^{2}(8)=17,402 \\
\mathrm{p}=0,026\end{array}$ & $\begin{array}{l}\text { Younger generations more } \\
\text { familiar. }\end{array}$ \\
\hline $\begin{array}{l}\text { I appreciate the beauty of } \\
\text { Malta's marine environment. }\end{array}$ & Education & $\begin{array}{l}\mathrm{x}^{2}(8)=16,069 \\
\mathrm{p}=0,041\end{array}$ & $\begin{array}{l}\text { Higher education linked to } \\
\text { stronger appreciation }\end{array}$ \\
\hline $\begin{array}{l}\text { I have a moral responsibi- } \\
\text { lity to do my part in protec- } \\
\text { ting the marine environment. }\end{array}$ & Edu & $\begin{array}{l}x^{2}(8)=21,741 \\
p=0,005\end{array}$ & $\begin{array}{l}\text { Higher education linked to } \\
\text { stronger sense of responsi- } \\
\text { bility }\end{array}$ \\
\hline $\begin{array}{l}\text { ESD related to MPAs is } \\
\text { important. }\end{array}$ & Age & $\begin{array}{l}x^{2}(8)=15,679 \\
p=0,047\end{array}$ & $\begin{array}{l}\text { Older generations value } \\
\text { environmental education } \\
\text { (EE) more }\end{array}$ \\
\hline $\begin{array}{l}\text { ESD provided by non-formal } \\
\text { sectors is valuable. }\end{array}$ & Gender & $\begin{array}{l}\mathrm{x}^{2}(4)=11,420 \\
\mathrm{p}=0,022\end{array}$ & $\begin{array}{l}\text { Men value EE provided by } \\
\text { NGOs more than women }\end{array}$ \\
\hline $\begin{array}{l}\text { Marine ESD should be } \\
\text { taught in all Maltese schools. }\end{array}$ & $\mathrm{Oc}$ & $\begin{array}{l}\mathrm{x}^{2}(8)=20,075 \\
\mathrm{p}=0,010\end{array}$ & Students least in favor. \\
\hline
\end{tabular}

\section{Discussion}

This study found that the Maltese public has limited knowledge about Malta's marine environment and MPAs. This result may be influenced by the existing challenge to ESD in Malta presented by the prevalent colonial mentality (Mifsud, 2010). Mayo, Pace and Zammit (2008) state that this colonial mentality has led the Maltese population to narrow their view to that of 'my home' as opposed to 'my environment'. As seen, $20 \%$ of the respondents were uncertain whether an MPA would benefit their family or community, pointing to a disconnected perception between that of their immediate environment and of the marine environment. Pace (2002) also pointed to Malta's reliance on British teaching materials as a reason behind the lack of attention paid to the marine environment within existing ESD initiatives. However, $42.5 \%$ of the respondents strongly agreed that marine ESD should be taught in all Maltese schools, suggesting a strong 
interest in heightening the importance given to marine ESD in Malta. With regards to the MPAs specifically, $91 \%$ of the respondents either strongly agreed $(41.5 \%)$ or agreed $(49.5 \%)$ that ESD related to MPAs is important. This finding is in line with that found by Trenouth et al. (2012) in Tasmania where respondents ranked "Education relating to MPAs is important" as 4.59 and 4.46 out of a scale of 5 for both study locations.

The Maltese public appears to hold a positive perception of MPAs since $85 \%$ of respondents either strongly agreed $(43.5 \%)$ or agreed $(41.5 \%)$ that they are in favour of MPAs. This finding is similar to that found by Thomassin et al. (2010) whereby $78 \%$ of the respondents on Reunion Island were in favour of the MPA in question. However, uncertainty appears to exist over to which extent the Maltese public believes it can and wants to be involved in marine conservation efforts. In fact, $43.5 \%$ of the sample was neutral towards wanting to have a say in decisions related to the management of Malta's MPAs. Mifsud (2012) and Pace (1997) have both pointed to the need for increased involvement of the Maltese public within decision-making processes, and the results of this study support these claims.

Mifsud (2011) identified the need to allocate more importance to outdoor education in Malta and, as highlighted within the results, $54 \%$ of the sample agreed that MPAs should be used for outdoor ESD. Pace (2002) identified the lack of marine educational experiences for children among the Maltese islands, and therefore MPAs may present an opportunity to address this lacuna. In addition, it was found that older generations in Malta value ESD related to MPAs more than younger generations, and so utilising Malta's MPAs to provide outdoor educations experiences targeted to children may increase their appreciation of the latter.

Based on the results of the study and the analysis of literature, a model is being proposed (Figure 4). This model aims to foster a sense of ownership among the Maltese public by encouraging their involvement in the management of local MPAs. The eight recommendations embedded within the model were chosen to strengthen the relationship between ESD and MPAs in Malta by addressing existing gaps and building on opportunities. The first recommendation is for current ESD programmes in Malta to expand their scope to include the marine environment, a central component of the local environment. This process is expected to be more efficient than creating new ESD programmes targeting, specifically, the marine environment. The second recommendation is to establish a mechanism allowing stakeholders to work cooperatively towards the management of Malta's MPAs since cooperation was identified as the preferred management approach during the interviews. The following recommendation is to address issues of implementation and enforcement surrounding Malta's MPAs. Stakeholders emphasised the need to establish MPA rules and regulations before being able to seriously discuss associated ESD initiatives. The fourth recommendation is to create partnerships between different entities in Malta to promote and deliver ESD related to MPAs. The combined levels of knowledge, experience and resources from a variety of organisations could facilitate the delivery of ESD programmes. The next recommendation is for the University of Malta to collaborate with MPA managers to meet data collection requirements for the MPAs. Students could participate in data collection for baseline studies and monitoring, which could present financial as well as educational benefits. The sixth recommendation is to promote information about Malta's marine environment to the public using media platforms, such as local television networks. The seventh recommendation is to explicitly include the marine environment under the National Curriculum Frame- 
work (NCF)'s ESD learning area. Currently, the NCF contains ESD as a learning area for junior and secondary students but does not mention the marine environment. Lastly, Malta's identity and heritage as an island nation should be utilised as a basis for marine ESD. This could foster an increased sense of ownership and responsibility towards the marine environment among the Maltese public. It is proposed that these actions be undertaken by a host of relevant stakeholders in Malta, including MEPA, local schools, the Centre for Environmental Education and Research (CEER), the Ministry for Education and Employment (MEDE), local communities as well as other stakeholders. The need to increase the involvement of local people in marine conservation efforts is clear, and it is hoped that the proposed model provides avenues to address this.

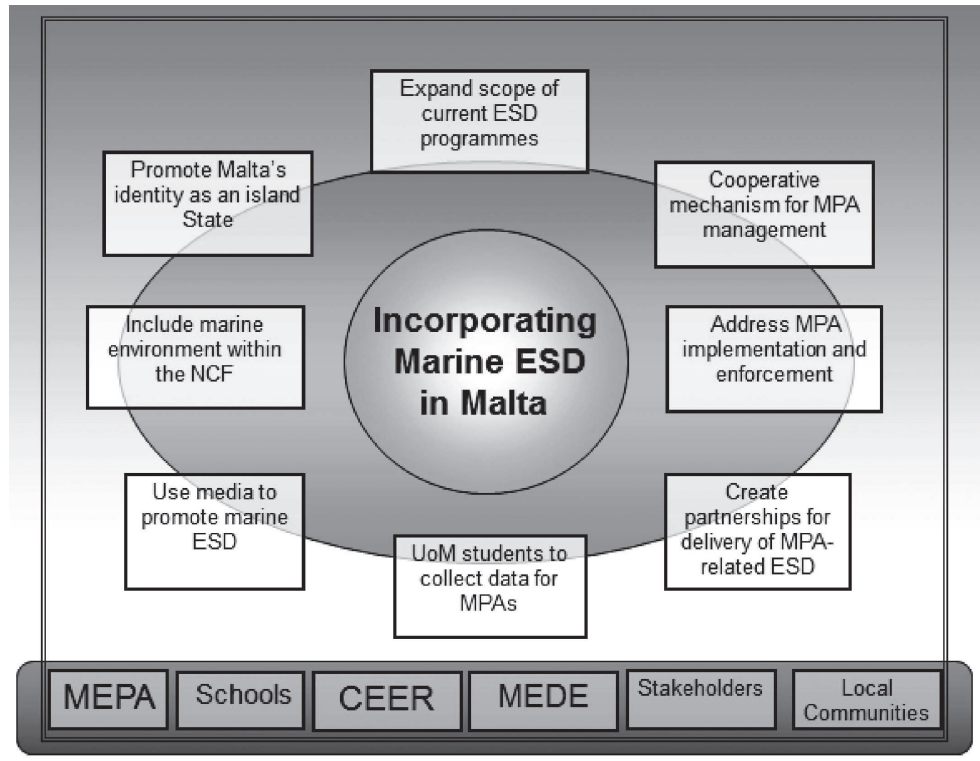

Figure 4. Proposed model to strengthen the relationship between ESD and MPAs in Malta

\section{Conclusion}

This work represents a baseline study on the Maltese public's knowledge and attitudes regarding the local marine environment and MPAs. Since the Maltese MPAs are not yet implemented, the findings can be used to inform the development of management mechanisms. Policy makers may utilise the findings to more effectively influence public awareness and to develop targeted ESD activities.

As one of the first studies examining marine ESD in Malta specifically, there are many existing areas for future research. Firstly, it would be valuable to perform a regional study of the Mediterranean region comparing people's knowledge and attitudes towards their local marine environment and MPAs while also comparing each country's ESD initiatives. This could shed light on the effectiveness of such programmes to inform the development of future marine ESD efforts. Within Malta, it would be important to investigate the behaviours adopted by the Maltese public towards the local marine environment as this was excluded from the scope of the present study. The results could 
be subsequently analysed along various socioeconomic indicators, such as age, gender, occupation status and highest level of education. Similarly to what was done by Leisher et al. (2012), it would be interesting to assess the knowledge and attitudes of the Maltese public after the institution of formal educational activities surrounding the MPAs. Comparing the findings to this study would determine whether the ESD activities were effective in influencing the public's knowledge and attitudes. Furthermore, it would be advantageous to evaluate future educational programmes targeting the MPAs in Malta as this would allow for adaptive management (Keene \& Blumstein, 2010) and address an existing gap within the field of ESD in Malta (Mifsud, 2011).

To conclude, the study has identified a lack of marine ESD in Malta even though the Maltese exhibit positive attitudes towards the marine environment and MPAs. For a small island state like Malta, an investment in increased marine ESD efforts could lead to important benefits for both the Maltese population and its surrounding marine environment.

\section{References}

Abdulla, A., Gomei, M., Hyrenbach, D., Notarbartolo-di-Sciara, G., \& Agardy, T. (2009). Challenges facing a network of representative marine protected areas in the Mediterranean: Prioritizing the protection of underrepresented habitats. ICES Journal of Marine Science, 66(1), 22-28.

Alder, J. (1996). Costs and effectiveness of education and enforcement, cairns section of the Great Barrier Reef Marine Park. Environmental Management, 20(4), 541551.

Behnam, A. (2013). Tracing the blue economy. Valletta: The Malta Foundation.

Bollmann, M., Bosch, T., Colijn F., Ebinghaus, R., Froese, R., Güssow, K., ... Weinberger, F. (2010). World ocean review: Living with the oceans. Hamburg: Maribus.

Coll, M., Piroddi, C., Steenbeek, J., Kaschner, K., Lasram, F. B. R., Aguzzi, J, ... Voultsiadou, E. (2010). The biodiversity of the Mediterranean Sea: Estimates, patterns, and threats. PloS ONE, 5(8), e11842. doi:10.1371/journal.pone.0011842

Cullis-Suzuki, S., \& Pauly, D. (2010). Marine protected area costs as "beneficial” fisheries subsidies: Aglobal evaluation. Coastal Management, 38(2), 113-121.

Government of Malta. (2002). Malta National Report. Available from https://www.um. edu.mt/_data/assets/pdf_file/0006/63699/Malta_WSSD.pdf

Guidetti, P., Baiata, P., Ballesteros E., Di Franco A., Hereu B., Macpherson, E., ... Sala, E. (2014). Large-scale assessment of Mediterranean marine protected areas effects on fish assemblages. PLoS ONE, 9(4), 1-14.

Keene, M., \& Blumstein, D. T. (2010). Environmental education: A time of change, a time for change. Evaluation and Program Planning, 33(2), 201-204.

Kelleher, G., (1999). Guidelines for marine protected areas. Gland \& Cambridge: IUCN.

Leisher, C., Mangubhai, S., Hess, S., Widodo, H., Soekirman, T., Tjoe, S., ... Sanjayan, M. (2012). Measuring the benefits and costs of community education and outreach in marine protected areas. Marine Policy, 36, 1005-1011.

Malta Environment and Planning Authority (MEPA). (2010). Four new marine protected areas. Retrieved August 1, 2014, from http://www.mepa.org.mt/outlook5-article2

Michel, L., Schnitzler, J., Dupont, A., Gobert, S., Nyssen, F., Dauby, P., \& Lepoint, G. (2011, February). Organisms as ecosystems engineers: The case of amphipod grazers 
from Posidonia oceanica meadows. Paper presented at the VLIZ Young Scientist Day, Brugge, Belgium.

Mangos, A., Bassino, J. P, \& Sauzade, D. (2010). The economic value of sustainable benefits rendered by the Mediterranean marine ecosystems. Valbonne: Plan Bleu.

Mangos, A., \& Claudot, M. A. (2013). Economic study of the impacts of marine and coastal protected areas in the Mediterranean. Valbonne: Plan Bleu.

Mayo, P., Pace, P. J., \& Zammit, E. (2008). Adult education in small states: The case of Malta. Comparative Education, 44 (2), 229-246.

Mifsud, M. C. (2010). Maltese youth and the environment: A qualitative study. Journal of Teacher Education for Sustainability, 12(2), 110-128.

Mifsud, M. C. (2011). An investigation on the environmental knowledge, attitudes and behavior of Maltese youth. US-China Education Review, 413-422.

Mifsud, M. C. (2012). Environmental education development in Malta: A contextual study of the events that have shaped the development of environmental education in Malta. Journal of Teacher Education for Sustainability, 14(1), 53-66.

National Statistics Office. (2013). Malta in figures 2013. Valletta: National Statistics Office.

Pace, P. (1997). Environmental education in Malta: Trends and challenges. Environmental Education Research, 3(1), 69-82.

Pace, P. (2002). The role of education in promoting the sustainable use of our marine resources. Valletta: Ministry of the Environment.

Personnic, S., Boudouresque, C. F., Astruch, P., Ballesteros, E., Blouet, S., Bellan-Santini, D., \& Ruitton, S. (2014). An ecosystem-based approach to assess the status of a Mediterranean ecosystem, the Posidonia oceanica Seagrass Meadow. PloS ONE, 9(6). doi: 10.1371/journal.pone.009899

Portman, M. E., Notarbartolo-di-Sciara, G., Agardy, T., Katsanevakis, S., Possingham, H. P., \& Di-Carlo, G. (2013). He who hesitates is lost: Why conservation in the Mediterranean Sea is necessary and possible now. Marine Policy, 42, 270-279.

Thomassin, A., White, C. S., Stead, S. S., \& Gilbert, D. (2010). Social acceptability of a marine protected area: The case of Reunion Island. Ocean \& Coastal Management, $53,169-179$.

Trenouth, A. L., Harte, C., Paterson de Heer, C., Dewan, K., Grage, A., Primo, C., \& Campbell, M. L. (2012). Public perception of marine and coastal protected areas in Tasmania, Australia: Importance, management and hazards. Ocean \& Coastal Management, 67, 19-29.

Worm, B., Barbier, E. B., Beaumont, N., Duffy, J. E., Folke, C., Halpern, B. S. ... Watson, R. (2006). Impacts of biodiversity loss on ocean ecosystem services. Science, 314(5800), 787-790.

United Nations Environment Programme (UNEP). (2006). Marine and coastal ecosystems and human well-being: A synthesis report based on the findings of the Millennium Ecosystem Assessment. Nairobi: UNEP.

Correspondence concerning this paper should be addressed to Dr Mark Mifsud, Centre for Environmental Education and Research, University of Malta, Msida, Malta. Email:mark.c.mifsud@um.edu.mt 